JAROSLAW PIETRZAK*

Instytut Historii i Archiwistyki

Uniwersytet Pedagogiczny im. Komisji Edukacji Narodowej w Krakowie

\title{
POBYT METROPOLITY MOLDAWSKIEGO DOZYTEUSZA W ŻÓŁKWI W LATACH 1686-1693, SPADEK PO NIM ORAZ SPRAWA KULTU ŚW. JANA NOWEGO (SUCZAWSKIEGO) DO KOŃCA XVIII WIEKU
}

Badania autora tekstu obejmujące sprawy przybycia i pobytu metropolity mołdawskiego Dozyteusza oraz przywiezienia przez niego skarbów, paramentów i szat liturgicznych, archiwaliów oraz najcenniejszego przedmiotu - relikwii świętego Jana Nowego (Suczawskiego) były już raz przedmiotem opracowania ${ }^{1}$. Dalsze kwerendy archiwalne w Lwowskiej Narodowej Naukowej Bibliotece Ukrainy im. Wasyla Stefanyka, Centralnym Państwowym Archiwum Historycznym Ukrainy we Lwowie oraz Archiwum Głównym Akt Dawnych w Warszawie postawiły pewne zagadnienia w nowym świetle i pozwoliły rozszerzyć zakres rozważań. Wynikiem tych badań jest niniejszy artykuł korygujący niektóre wcześniejsze ustalenia, a w innych miejscach rozszerzający dotychczas postawione tezy.

$$
* * *
$$

Mołdawska wyprawa Jana III Sobieskiego w I686 r. uwarunkowana była chęcią kontynuowania rozpoczętej trzy lata wcześniej walki przeciw Turkom. Król dążył po pierwsze, do zajęcia twierdz naddunajskich i zdobycia Kilii, Białogrodu, Reni i Izmaiłu, co zneutralizowałoby wpływ Turcji na Chanat Krymski oraz wymusiłoby poddanie się tureckich załóg w Jazłowcu, Kamieńcu Podolskim, Barze i Międzyborzu. Po drugie, monarsze zależało na podporządkowaniu Mołdawii i osadzeniu na jej tronie hospodarskim własnego zwolennika. Po trzecie, chciano zbliżyć się do Wołoszczyzny i wraz z wojskami tamtejszego hospodara Serbana Cantacuzino (I640-I688) wywołać powstanie przeciw Turcji. Na ostatek, po

\footnotetext{
* Jarosław Pietrzak - absolwent Uniwersytetu Łódzkiego, doktor nauk humanistycznych w zakresie historii, adiunkt w Katedrze Historii Nowożytnej (Instytut Historii i Archiwistyki Uniwersytet Pedagogiczny im. Komisji Edukacji Narodowej w Krakowie). Autor książki pt. Księżna dobrodziejka. Katarzyna z Sobieskich Radziwiłłowa (1634-1694) - życie i działalność (Warszawa 2016). Współpracownik Muzeum Pałacu Króla Jana III w Wilanowie, stypendysta Fundacji Lanckorońskich z Brzezia. E-mail: jaroslawpietrzak777@gmail.com.

1 Tekst pt. Metropolita, święte relikwie i skarby. Jeszcze raz o pobycie władyki mołdawskiego Dozyteusza w Polsce w latach 1686-1693 i kwestii spadku po nim ukazał się w tomie Conferinţa ştiinţifică internaţională: Dialectica necesităţii şi libertăţii în educaţie, Chişinău 30 martie - 1 aprilie 2016, red. V. Constantinov, N. R. Pikuła, J. Bartoszewski, Chişinău 2016.
} 
przejęciu kontroli nad Siedmiogrodem, król zamierzał wesprzeć armię cesarską walczącą na Węgrzech².

Polityczne i militarne wydarzenia toczące się w obrębie I686 r. nie będą tu szczegółowo prezentowane, z uwagi na to, że zostały już opracowane ${ }^{3}$. Warto dodać tylko, że zgoda na pierwszą wyprawę do Mołdawii zapadła na radzie senatu w lipcu I684 r. Kłótnie trwające w otoczeniu króla, a przede wszystkim konflikt monarchy z hetmanami wielkimi, koronnym Stanisławem Janem Jabłonowskim (I634-I702) i litewskim Kazimierzem Janem Sapiehą (I637-I720), przyczynił się wkrótce do klęski wojska w okolicach Żwańca. Nowe plany ekspedycji w kierunku Mołdawii pojawiły się wiosną I685 r. Jan III domagał się wówczas, by cesarz przysłał posiłki, które wsparłyby wojsko polsko-litewskie. Tak sformowana armia po przejściu Mołdawii i Wołoszczyzny skierowałaby się ku Siedmiogrodowi i zmusiłaby księcia Michała Apafiego (I632-I690) do opowiedzenia się po stronie Świętej Ligi. Brak jednoznacznego poparcia ze strony Leopolda I wymógł na królu ograniczenie planów. Zostały one skonkretyzowane na naradzie wojennej na początku grudnia I685 r.

Sobieski snuł - poza potrzebą walki z Turkami - także własne dalekosiężne plany na wypadek powodzenia kampanii i zajęcia Mołdawii. Były nimi zorganizowanie akcji ofensywnej w kierunku Kamieńca Podolskiego, wsparcie misji rzymskokatolickich duchownych oraz oddanie tronu hospodarskiego któremuś ze swych synów, w konsekwencji czego doszłoby do utworzenia na podbitych terenach monarchii dziedzicznej. Szczególnie ten ostatni motyw stał się powodem krytyki króla przez środowisko niechętnej mu magnaterii ${ }^{4}$.

Wymarsz armii polskiej 20 lipca I686 r. spotkał się z natychmiastową reakcją cesarza Leopolda I, który życzył królowi polskiemu rychłego zwycięstwa i szczęśliwego powrotu5. Traktem przez Chocimierz, Sambor, Winograd, Uścieszko, Śniatyń, armia skierowała się ku lewemu brzegowi Prutu, a następnie wkroczyła w gęstwinę lasów bukowińskich. Dalszy marsz przez Toporowiec, Marszowce, Peretytę, Cecorę zakończył się w połowie sierpnia

2 Cz. Chowaniec, Wyprawa Sobieskiego do Mołdawii w 1686 r., wyd. 2, Oświęcim 2015, s. 13; E. Baidaus, Księstwo mołdawskie $w$ polityce zagranicznej Polski od zwycięstwa pod Wiedniem do zawarcia pokoju kartowickiego (1683-1699), „Balcanica Posnaniensia”, 2003, t. 13, s. 215-221.

3 Na ten temat szczegółowo: Cz. Chowaniec, op. cit., s. 124; idem, Z dziejów polityki Jana III Sobieskiego na Bliskim Wschodzie 1683-1686, „Kwartalnik Historyczny”, 1926, t. 40, s. 151-160; idem, Z dziejów powiedeńskiej polityki Jana III. Do genezy sprawy wschodniej, „Przegląd Współczesny”, 1929, t. 30, s. 321-341; idem, Miron Costin en Pologne, contributions à l'année 1684-1685, Cluj 1931; S. Iorga, Sobieski et les Roumains 1683-1696, Paris 1933; M. Kasterska Sergescu, L'expédition de Sobieski en Moldavie en 1686, „Revue Historique du Sud-Est Européen", 1933, vol. 10, fasc. 1, s. 17-30; Z. Spieralski, Awantury mołdawskie, Warszawa 1967; V. Ciobanu, Jan III Sobieski $w$ historiografii rumuńskiej, „Śląski Kwartalnik Historyczny. Sobótka”, 1980, t. 35, z. 2, s. 223-227; J. Woliński, Z dziejów wojen polsko-tureckich, Warszawa 1983, s. 51-59; Z. Wójcik, Jan Sobieski 1629-1696, Warszawa 1983, s. 378-384; I. Czamańska, Oswobodziciel czy najeźdźca? Polityka Jana III Sobieskiego wobec hospodarstw Mołdawii i Woloszczyzny, „Roczniki Historyczne”, R. 55-56, 1989/1990, s. 151-177; M. L. Sileoni, La difficile campagna militare anti-turca in Moldavia di Jan III Sobieski (1686) nella carte vaticane, w: L'Europa centro-orientale e pericolo turco tra Sie- e Settecento. Atti del Convegno Internazionale (Viterbo, 23-25 Novembre 1998), red. G. Platania, Viterbo 1998, s. 173-191; F. De Caprio, Il tramonto di un regno. Il declino di Jan Sobieski dopo il trionfo di Vienna, Viterbo 2014, s. 89-175.

4 L. Hopp, Ruch niepodległościowy szlachty węgierskiej przeciwko Habsburgom a Sobieski, „Śląski Kwartalnik Historyczny. Sobótka", 1980, t. 35, z. 2, s. 229-235; J. Staszewski, Królewicz Aleksander Sobieski kandydatem do korony węgierskiej, „Śląski Kwartalnik Historyczny. Sobótka”, 1980, t. 35, z. 2, s. 391-398; I. Czamańska, Oswobodziciel..., s. 164; A. Skrzypietz, Królewscy synowie - Jakub, Aleksander i Konstanty Sobiescy, Katowice 2011, s. $147-150$.

5 Leopold I do Marii Kazimiery d'Arquien Sobieskiej, Viennae, 31 X 1685, Нацыянальны гістарычны архіў Беларусі (dalej: НГАБ), fond 695, opis 1, nr 129, k. 1-1v. 
w stolicy hospodarstwa Jassach. Sobieski wobec braku przychylności ze strony hospodara Konstantego Kantemira (I6I2-I693) próbował przeciągnąć na swoją stronę bojarów oraz żołnierzy, aby móc ruszyć przeciw Tatarom budziackim6.

Uroczystość wjazdu Jana III do Jass, poprzedziło przyjęcie przez monarchę delegacji pod przewodnictwem metropolity mołdawskiego Dozyteusza (Doziteusza, Dosoftieja, Dosofteia), który w obozie wygłosił mowę na cześć Jana III „,pełną czci i uległości [...] Biskup powtórzył po wielokroć, że może spokojnie umierać, widząc swe owieczki podległe władzy równie sprawiedliwej i prawej jak tyrańska i okrutna była władza poprzednia" . Dozyteusz następnie długo rozmawiał z królem o sytuacji politycznej w kraju, a na koniec wizyty poprosił w imieniu ludności miasta o jak najszybszy uroczysty wjazd.

Zgodnie z przekazem francuskiego dyplomaty, inżyniera i pamiętnikarza Philippa le Massona (Duponta) (po I650-I726), król nie pragnął owacji na swą cześć i starał się odwlec uroczystość. Kiedy Jan III nie mógł już zwlekać - jak twierdzi autor przekazu - wziął ze sobą pięciuset lub sześciuset konnych i udał się bezpośrednio do zamku. Dupont pozostawił po sobie dość długi opis miasta, zawierający informacje o jego położeniu oraz mieszkańcach stolicy. Odmalował obraz Jass zabudowanych zamkami oraz monasterami, miasta zniszczonego wojnami, lecz - jaki wspominał - niegdyś stanowiącego ośrodek handlu towarami z dalekich terenów Azji ${ }^{8}$. Triumfalny wjazd Sobieskiego do Jass I6 sierpnia I686 r. wypełniony był okrzykami radości i aplauzami wznoszonymi przez lud stolicy hospodarstwa. Możni, oddziały wojska i mieszczanie składali polskiemu królowi akty czołobitności. Wszyscy oni w uformowanym szpalerze, przy wtórze hymnów i z ikonami w dłoniach, doprowadzili króla do katedry przed oblicze metropolity. Zgodnie z relacją uczestniczącego w wyprawie królewicza Jakuba Ludwika Sobieskiego „po odśpiewaniu Te Deum ad Metropolitanam pojechaliśmy, gdzie nas sam przyjmował metropolita sędziwy, a infuła jego na kształt korony klejnotami ozdobiona. Nosił krzyż na piersiach, ten, co mu posłał król JM. Cerkiew ozdobiona malowaniem nawet in atrium do kościoła"9. Inna relacja stwierdza, iż metropolita powitał króla oracją w asystencji $200 \mathrm{księży}{ }^{10}$, a po krótkiej rozmowie oprowadził monarchę po ważniejszych monastyrach ${ }^{\mathrm{II}}$.

Kluczową postacią dla tej opowieści jest osoba metropolity Dozyteusza (właść. Dymitra Baryły lub Baryłowskiego), pochodzącego według różnych wersji bądź z rodziny drobnych bojarów, bądź z rodziny kupieckiej lub z Ukrainy. Obecnie przyjmuje się, że Dozyteusz był rodowitym Rumunem. Jako młodzieniec, Dymitr zdobył wykształcenie najpierw w Jassach i być może we Lwowie, które następnie poszerzył w mołdawskich monasterach Secu i Probata. Tamże w I649 r. przyjął święcenia kapłańskie i nowe imię - Dozyteusz. W I658 r. został biskupem Huşi, a rok później biskupem w Romanie. W I67I r. został wybrany metropolitą

6 D. Cantemir, Vita Constantyni Cantemyri, cognomento senis Moldaviae Principis, w: idem, Opere principelui Demetriu Cantemiru publicate, t. VII, ed. Academia Română, Bucureşti 1883, s. 40.

7 P. Dupont, Pamiętniki historyi życia i czynów Jana III Sobieskiego, tłum. B. Spieralska, wstęp i oprac. D. Milewski, Warszawa 2011, s. 282.

8 Ibidem.

9 J. L. Sobieski, Diariusz kampanii w wołoskiej ziemi 1686 r. królewicza Jakuba Sobieskiego, w: Cz. Chowaniec, Wyprawa..., s. 104.

10 Ritretto della Operationi dell Armata del Re di Polonia, dalli 4 Giugno giorno della partenza di sua Maestà da Javorova sino all'acquisto della Moldavia, w: Relacje nuncjuszów apostolskich i innych osób o Polsce od roku 1548 do 1690, wyd. E. Rykaczewski, t. 2, Berlin-Poznań 1864, s. 446-447.

11 P. Dupont, op. cit., s. 282. 
mołdawskim $^{12}$. Na przełomie I673 i I674 r., wraz z hospodarem Stefanem Petriceicu (zm. po I684), Dozyteusz znalazł się w grupie bojarów i wojskowych, którzy opowiedzieli się po stronie polskiej w konflikcie z Turcją. Z tej racji zmuszeni zostali opuścić Mołdawię i wybrać gościnę zaoferowaną im przez marszałka i hetmana wielkiego koronnego Jana Sobieskiego W należącym do niego starostwie stryjskim ${ }^{13}$. W czasie drugiego pobytu Dozyteusza w Polsce w I675 r., wymuszonego przeciągającą się okupacją Jass przez wojska polskie, został on pozbawiony urzędu metropolity mołdawskiego. Poza sporadycznymi kontaktami z carem Aleksiejem Michajłowiczem Dozyteusz zajął się działalnością naukową i pisarską. Podczas pobytów w monastyrach bazyliańskich w Kryłosie i Uniewie koło Żółkwi Dozyteusz opracował w latach I675-I683 m.in. Akafist Najświętszej Panny, Święta Liturgię, Żywoty Świętych, Maty Efchologion oraz Maty modlitewnik ${ }^{14}$.

Cechą niewątpliwie wyróżniającą Dozytusza była jego uczoność i wynikająca z niej twórczość literacka. Kronikarz Ion Neculce (I672-I745) sportretował metropolitę w następujący sposób: „Tenże metropolita Dosofteusz nie był człowiekiem głupim. Był z rodu szlacheckiego, wyedukowanym, znającym wiele języków: grekę, łacinę, słowiański i inne głębokie księgi naukowe, prawdziwy mnich i świątobliwy mąż, i łagodny jak baranek. W naszym kraju aż dotąd nie było człowieka jak on"'5. Faktycznie, Dozyteusza uznać należy nie tylko za najważniejszego dostojnika duchownego Mołdawii, ale przede wszystkim za inicjatora wprowadzenia języka mołdawskiego do liturgii i kancelarii hospodarskiej. Jego pomnikowe dzieło Psâltirea Svîntului prooroc David pre versuri tocmită (Uniev. I673) inspirowane było twórczością Jana Kochanowskiego ${ }^{16}$. Poza tym Dozyteusz uznawany jest za twórcę pierwszego poematu historycznego Poem cronologic despre domnii Moldovei opublikowanego w ostatnim ćwierćwieczu XVII w. ${ }^{17}$. Zasługi Dozyteusza dla literatury i oświaty mołdawskiej związane były ponadto $\mathrm{z}$ faktem erygowania w I680 r. w Jassach drukarni ${ }^{\mathrm{I}}$.

Pobyt króla w Jassach nie trwał długo. Tuż po wkroczeniu do stolicy hospodarstwa Jan III zdecydował o dalszym marszu na Budziak, który był siedzibą ordy Tatarów. Wobec przedłużającego się marszu, jak również braku widoków na bitwę z wojskami sułtana, wśród polskich dowódców coraz częściej mówiono o konieczności przerwania wyprawy. Król nie był w stanie przekonywać dłużej rady wojennej do słuszności swoich racji i 2 września I686 r.

\footnotetext{
12 O życiu Dozyteusza szczegółowo: Ş. Dinulescu, Viaţa şi scrierile lui Dositeiu mitropolitul Moldovei, „Candela", 1885, t. 4, s. 69-423; D. Dan, Dosoftei, mitropolitul Moldovii 1624-1693, Cernăuţi 1927; M. Sokołowski, Spadek po metropolicie Doziteuszu i jego losy, „Sprawozdania Komisyi do badań historii sztuki PAU”, 1889, t. 4, z. 2, s. 15-18; T. Cojocaru, Metropolita suczawski Dosoftei (1624-1693) a Rzeczpospolita, „Balcanica Posnaniensia”, 2003, t. 13, s. 235-238 (tam szczegółowa literatura przedmiotu).

13 J. Woliński, Po Chocimie 1673-1674, „Przegląd Historyczny”, 1948, t. 37, s. 288-305; idem, Ze spraw polsko-mołdawskich 1672-1673, w: Z dziejów wojen polsko-tureckich, red. J. Woliński, Kraków 1983, s. 51-59; I. Czamańska, Oswobodziciel..., s. 151-158; eadem, Rumuńska imigracja polityczna w Polsce XVII wieku, „Balcanica Posnaniensia", 1993, t. 6, s. 17-19; D. Milewski, Wojenne interludium. Stosunki polsko-mołdawskie w latach 1676 -1683, w: Król Jan III Sobieski i Rzeczpospolita w latach 1674-1683, red. D. Milewski, Warszawa 2016, s. $227-257$.

14 E. Biedrzycki, Zarys dziejów literatury rumuńskiej, Lwów 1935, s. 29-33; T. Cojocaru, op. cit., s. 238-240.

15 I. Neculce, Letopiseţul Tării Moldovei de la Dabija-Vodă până la a doua domnie a lui Constantin Mavrocordat, red. A. şi Dan Vidraşcu, Chişinău 2001, s. 93-94.

16 H. Masterski, „, Psaltirea în versuri” metropolity mołdawskiego Dosofteia w „Psałterz Dawidów” Jana Kochanowskiego, Poznań 1966.

17 I. Czamańska, Miron Costin. Życie i twórczość, w: Latopis ziemi mołdawskiej i inne utwory historyczne, wyd.

I. Czamańska, Poznań 1998, s. 47-49, 59.

18 M. Sokołowski, op. cit., s. 18.
} 
pod Falczynem (ok. 40 km od Dunaju) wydał rozkaz odwrotu, a właściwie „strategicznego kontrmarszu". Po trudnym odwrocie siły polskie powróciły do Jass I4 września ${ }^{19}$. Monarcha wierzył, że w stolicy uda mu się przezimować i na wiosnę następnego roku wznowić działania wojenne. Tymczasem następnego dnia po lustracji zabudowań miejskich, zamku i przeprowadzaniu robót fortyfikacyjnych wybuchł pożar, którego źródło zlokalizowano w magazynie z żywnością. Odpowiedzialnością za podpalenie obarczono Kozaków i podjazdy tatarskie, które niszczyły przedmieścia ${ }^{20}$. Na radzie wojennej zwołanej I7 września król - mając na względzie wielkość zniszczeń, brak dostępu do wody i zapasów oraz odcięcie od pozostałych jednostek operacyjnych - zadecydował o powrocie do kraju. Decyzja monarchy podyktowana była ponadto obawą przed zbliżającymi się oddziałami hospodara Kantemira, jak i chęcią połączenia się w trakcie marszu z oddziałami Serbana Cantacuzino celem przeniesienia walk do Siedmiogrodu.

Decyzja o opuszczeniu Jass pociągnęła za sobą, w sposób naturalny, przygotowanie aprowizacji na drogę. Żywność była wykupywana lub zbierana po monasterach. W tym miejscu opowieść dociera do wydarzenia przełomowego z punktu widzenia tematu. Do grupy 40 znaczniejszych bojarów podążających wraz z Sobieskim dołączył metropolita Dozyteusz. Duchowny wiózł ze sobą przedmioty ze skarbca katedralnego, dokumenty archiwum metropolitalnego oraz relikwie patrona Mołdawii św. Jana Nowego ${ }^{21}$.

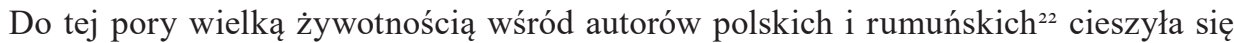
wersja, jakoby Jan III obrabował mołdawskie monastery, w tym suczawski, w którym zdeponowane były relikwie św. Jana Nowego. Powtarzano też, że król czynił wielkie trudności hospodarowi Kantemirowi z wydaniem skarbu, archiwum i oczywiście relikwii ${ }^{23}$. Informacje te mają swój początek w dziele Dymitra Kantemira, spisanym w wieku XVIII na podstawie relacji ustnych hospodara. Podobny wydźwięk ma relacja kronikarska Iona Neculce: „Następnie król wziął Dosofteusza metropolitę jaskiego [właściwie: mołdawskiego ze stolicą w Suczawie - przyp. J.P.] ze wszystkimi ubraniami i klejnotami metropolitalnymi. Wzięto

19 Cz. Chowaniec, Wyprawa..., s. 58-78; Francesco Bonesana i wojna turecka (1684-1691), w: M. Wagner, W cieniu szukamy jasności chwaty. Studia z dziejów panowania Jana III Sobieskiego (1684-1696), Siedlce 2002, s. 141-142 .

20 Plotka powiadała, że to król nakazał podpalić Jassy, by dać tym sygnał do rabunku stolicy. Zarzucano też monarsze, że własnoręcznie podpalił trzy monastery: D. Cantemir, op. cit., s. 44.

21 Według legendy, Jan Nowy był greckim kupcem z Trapezuntu, zamęczonym ok. 1330 r. przez Persów. Kult św. Jana Nowego (zwanego też Suczawskim) rozwinął się na terenie Mołdawii w początkach XV w. wraz ze sprowadzeniem jego relikwii przez hospodara Aleksandra Dobrego (1375-1432) z Białogrodu nad Dniestrem do Suczawy. W końcu tego wieku nastąpiła popularyzacja legendy hagiograficznej o świętym za sprawą mnicha, prezbitera Cerkwi wołosko-mołdawskiej, a później metropolity kijowskiego Grzegorza Camblaka (ok.1362-1419/1420) oraz hospodara Stefana Wielkiego (1457-1504). Święty tytułowany był już wówczas patronem Księstwa Mołdawskiego i Cerkwi wołosko-mołdawskiej. W XVI i XVII w. z inicjatywy rodu Mohyłów wznoszono cerkwie ku czci św. Jana (Voroneţ, Roman, Bistriţa, Dobrovaţ, Suceviţa), zdobione malowidłami ukazującymi jego życie i cuda. Rozwój literatury cerkiewnej, a w ślad za nią folkloru religijnego związanego z kultem św. Jana oraz zagrożenie tureckie sprawiło, iż Jan Nowy stał się symbolem oporu przeciw poganom. Grób świętego traktowany był jako miejsce cudowne. W ten sposób relikwie zyskały status palladialny, tj. przedmiotu napełnionego mocą zdolną chronić naród przed wrogami prawosławia. Św. Jan Nowy począł być nawet tytułowany „rycerzem Chrystusowym”: E. Kocój, Przepis na patrona. O kulcie Jana Nowego Suczawskiego na ziemiach rumuńskich, w: Sprawozdania z posiedzeń Komisji PAN, 1999, t. 43/1, s. 18-19; eadem, Światynie-postacie-ikony. Malowane cerkwie i monastyry Bukowiny Poludniowej w wyobrażeniach rumuńskich, Kraków 2006, s. 322-346.

22 Szczegółowo o tym: M. Sokołowski, op. cit., s. 10-11.

23 D. Cantemir, op. cit., s. 44-45. 
także relikwie świętego Jana Nowego z Suczawy, które to relikwie sprowadził był tu z Turcji hospodar Aleksander Dobry. I poprowadził te relikwie wraz z metropolitą Dosofteuszem do Polski króla Sobieskiego, mianowicie do Żółkwi do cerkwi na targu, gdzie znajdują się do dzisiaj’"24. Ówcześni oraz późniejsi autorzy postrzegali Jana III już nie jako mężnego monarchę, który pokonał Turków, ale jako zbrodniarza, który wykradł ich narodowe świętości ${ }^{25}$.

Tymczasem sprawa wyjazdu Dozyteusza z Jass wraz z relikwiami rysuje się zgoła inaczej $^{26}$. Relacje naocznych świadków wskazują, że metropolita nie z przymusu, lecz w obawie przed zemstą hospodara Kantemira zdecydował się na wyjazd. Zabierając relikwie, aparaty kościelne oraz dokumenty kierował się troską o los tych przedmiotów na wypadek zajęcia Jass i Suczawy przez Turków lub Tatarów. Tak informował ambasador wenecki przy polskim monarsze Girolamo Alberti: „niektórzy mieszkańcy [Jass - przyp. J.P.] oddali się pod protekcję króla polskiego, wśród nich był metropolita biskup grecki [Dozyteusz - przyp. J.P.], mający Turków za przeciwników, o czym ci dobrze wiedzieli’’27. Niebezpieczeństwo najazdu tatarskiego było w tym czasie wielce prawdopodobne, o czym świadczą z kolei źródła francuskie autorstwa ambasadora Françoisa Gastona de Béthune'a (I638-I693)28 oraz pamiętnikarza Françoisa Paulina Daleraca ${ }^{29}$. Innym dowodem na to, że Dozyteusz zamierzał uchronić święte relikwie przed profanacją, są jego własne słowa zawarte w liście do carów Aleksieja, Piotra i Zofii Aleksiejewny z I688 r.: ,jesteśmy na tułaczce w Stryju, gdzie czekamy póki w kraju się nie uspokoi i będzie nam dozwolone wrócić ze wszystkim, co zabraliśmy i z Wielkim Męczennikiem Janem Suczawskim do ojczyzny do Suczawy, obecnie pustoszonej i dewastowanej”30. Później nawiązywali do tego Mołdawianie w petycji z I769 r. do carycy Katarzyny II, w której zwracali się z prośbą o zwrot relikwii do Jass, zaznaczając, że metropolita Dozyteusz wywiózł je do Polski wraz ze skarbem i z archiwum dla ochrony przed rabunkiem, ale z zamiarem zwrotu ${ }^{31}$. Niezależnie od tego, wyjazd metro-

\footnotetext{
24 I. Neculce, op. cit., s. 94.

25 S. Wędkiewicz, Z tradycji rumuńskich o Janie III Sobieskim, w: Studia staropolskie. Księga pamiątkowa ku czci Aleksandra Brücknera, Kraków 1928, s. 670-679; J. Śliziński, Jan III Sobieski w literaturze narodów Europy, Warszawa 1979, s. 402-403; I. Czamańska, Oswobodziciel..., s. 176-177; eadem, From the Moghilas to Dosoftei. The Polish-Romanian Relations in the 17th Century, w: Romanian and Polish Peoples in East-Central Europe (17th-20th), red. V. Ciobanu, Iaşi 2003, s. 24-27.

26 O dyskusji na temat wyjazdu metropolity Dozyteusza w historiografii rumuńskiej: T. Cojocaru, op. cit., s. 246-247 .

27 Girolamo Alberti do doży weneckiego Marcantonia Giustiniani, pola nad Prutem, 29 IX 1686, Biblioteka Polskiej Akademii Umiejętności - Polskiej Akademii Nauk w Krakowie (dalej: B. PAU-PAN), Teki Cieszkowskiego, sygn. 8700, s. 322-323. W podobnym tonie utrzymane zostały relacje: Giovanni Battista Romanini do kardynała Carlo Barberini, Vienna, 20 X 1686, B. PAU-PAN, Teki Rzymskie, sygn. 8442, t. 102, s. 20; Tomasz Talenti do Kosmy III Medyceusza, 29 IX 1686, w: Lettere militari con un piano di riforma dell'esercito polacco del Re Giovanni Sobiecki(!) ed altre de suoi segretari italiani al Gran Duca di Toscana Cosimo ed alla sua segretaria trovate e pubblicate da Sebastiano Ciampi, presso Borgii e Compagni, Firenze 1830, s. 61-62.

28 François de Béthune do Colberta de Croissy, obóz nad Seretem, 27 IX 1686, w: Documente privatore la Istoria Românilor culese de Eudoxiu de Hurmuzaki. Corespondenţa diplomatică şi rapoarte consulare franceze (1603-1824) publicate dupā copile Academiei Române de Nerva Hodoş, t. 16, Bucureşti 1912, s. 134.

29 F. P. Dalerac, Les anecdotes de Pologne ou mémoires secrets du règne de Jean Sobieski III du nom, Amsterdam 1699 , t. 2, s. 199-200.

30 Dozyteusz do carów Piotra, Aleksieja i Zofii Aleksiejewny, Stryj, 27 I 1688, w: S. Dragomir Contributi privitoare la relatiile bisericii românesti cu Rusia în veacul al. XVII-lea, „Annale Academiei Române, Sectiunea Istorie, seria II", Bucuresti 1911-1912, aneks list XXXVII, s. 1204.
}

31 Ş. Dinulescu, op. cit., s. 477-479. 
polity i przejęcie przez Sobieskiego relikwii św. Jana było szeroko komentowane w samym obozie pośród szlachty. Pisał o tym m.in. słynny pamiętnikarz Jan Chryzostom Pasek: „To tylko najznaczniejsze, że św. Iwan przeniósł się na rezydencję z Wołoch do Polski cum tota aregentea supellectili' ${ }^{2}$.

Droga powrotna wojsk polskich oraz mołdawskich emigrantów wiodła przez Krasny-Targ i Peretytę ku Śniatyniowi. Pospieszny marsz odbywał się w atmosferze stałego zagrożenia atakiem Tatarów lub wojsk hospodarskich. Dopiero w połowie października I686 roku król zadecydował o rozlokowaniu wojsk na Wołyniu, Pokuciu, w Trembowli, w Wiśniowcu i w Międzybożu. Po tej dyspozycji oddał komendę hetmanowi Jabłonowskiemu, a sam wraz z synem udał się do Stryja ${ }^{33}$. W orszaku królewskim znalazł się też metropolita Doyzteusz, archimandryta suczawski Mikołaj, trzech czerńców - Adrian, Jonasz i Hilarion opiekujących się relikwiami św. Jana Nowego oraz wzięci w jasyr Tatarzy budziaccy ${ }^{34}$. Od tego czasu aż do I69I r. - kiedy ciało świętego przewieziono do Żółkwi - metropolita rezydował w Stryju, mieście zamieszkiwanym w XVII wieku w większości przez prawosławnych i emigrantów mołdawskich ${ }^{35}$. Wiadomo, że w tym okresie Dozyteusz uczestniczył w szeregu uroczystości religijnych: „Po tym jak został uwieziony, król Sobieski odział go w najdroższe szaty i klejnoty metropolii naszego kraju, aby sprawował liturgię w święto Jordanu i Trzech Króli, według obyczaju naszego kraju, i podziwiali król i wszyscy panowie polscy i chwalili piękną ceremonię, jaką ma Cerkiew naszego kraju"36. Poza tym metropolita konsekrował kilku duchownych na urząd episkopa. Wyświęcił m.in. Metodego Rakowickiego na biskupa Munkacza W I687 r. oraz Atanazego Szumlańskiego na biskupa łuckiego, co pozwala przypuszczać, że posiadał uprawnienia egzarchy patriarchatu konstantypolitańskiego. Jednocześnie Dozyteusz poświęcił się walce z wpływami unii i działalnością biskupa Józefa Szumlańskiego, który siłą odbierał prawosławnym cerkwie i monastyry ${ }^{37}$ oraz przekładom dzieł teologicznych i liturgicznych z języka greckiego na ruski. Dozyteusz niejednokrotnie narzekał jednak na warunki życia, prosząc w I690 roku cara o zapomogę i pomoc w powrocie do metropolii suczawskiej ${ }^{8}$.

Tuż po wyjeździe Dozytuesza hospodar Konstanty Kantymir w styczniu i grudniu I687 r. upominał się o zwrot relikwii, jednak metropolita stanowczo odmówił jego prośbom. Wówczas podobne napomnienia, aż trzykrotnie, wystosowywał do metropolity mołdawskiego patriarcha jerozolimski Dozyteusz II (pontyfikat w 1. I669-I707). Zignorowanie tych nacisków

\footnotetext{
32 J. Ch. Pasek, Pamiętniki, t. 2, wyd. S. Sierpowski, Wrocław 2006, s. 498-499. Osobno wspominał o tym fakcie król Jan III Sobieski w liście do Michała Stefana Radziejowskiego, Stryj, 12 XI 1686, Biblioteka Kórnicka Polskiej Akademii Nauk w Kórniku (dalej: BK), sygn. 1596, k. 49r.-50r.

33 J. L. Sobieski, Diariusz kampanii..., s. 113-114.

34 Regestr Niewolników zesłanych do Stryja 30 Octobra 1686, BK, sygn. 1559, k. 53r.-54v; S. Barącz, Pamiątki miasta Żółkwi, Lwów 1852, s. 54; Mołdawianie i Serbowie w służbie Jana III Sobieskiego (1685-1686), w: M. Wagner, op. cit., s. 116-123.

35 A. Prochaska, Historia miasta Stryja, Lwów 1926, s. 97-100. Jan III Sobieski przeznaczył 200 złotych polskich na przyjęcie relikwii oraz zapewnienie im należnego miejsca kultu: НГАБ, f. 694, op. 2, nr 2460, k. 242.

36 I. Neculce, op. cit., s. 94.

37 Tatiana Cojocaru przypuszcza, że walka z wpływami Józefa Szumlańskiego w latach 1692-1693 spowodowana była nie tylko zwalczaniem wpływów unii. Dozyteusz udzielił bowiem poparcia swemu krewnemu Kiriakowi Paparze, który został obłożony klątwą przez Szumlańskiego. Szerzej: T. Cojocaru, op. cit., s. 248.

38 Dozyteusz do carów Piotra, Aleksieja i Zofii Aleksiejewny, Stryj, 27 I 1690 (oraz 9 I 1691 i 20 IX 1693), w: S. Dragmoir, op. cit., s. 1208, 1213-1214, 1218-1219 (listy nr XXXIX, XLII, XLVI).
} 
spowodowało rzucenie klątwy na metropolitę mołdawskiego: „Lecz nic go nie dotknęło, ponieważ mówią ludzie, że był świętym”39. Momentem przełomowym okazało się uroczyste przeniesienie relikwii św. Jana ze Stryja do Żółkwi, do założonego pięć lat wcześniej przez Jana III monasteru bazyliańskiego ${ }^{40}$. Wydarzenie to postrzegać należy w kategoriach kapitulacji Dozyteusza wobec szerzącej się na terenach Rusi Czerwonej idei unii oraz jako wyraz propagandy szerzonej przez króla i osoby związane z jego otoczeniem dla podniesienia splendoru rodu Sobieskich ${ }^{4}$. Sam akt uroczystej introdukcji relikwii odbył się z wielką pompą: „którą uroczystość w przytomności całej ziemi lwowskiej odprawił się mającą Najjaśniejszy Monarcha zalecił Jaśnie Wielmożnemu Józefowi Szumlańskiemu biskupowi lwowskiemu, aby powagą swoją ten akt potwierdził i zaszczycił. Za czym gdy wszelka gotowość stanęła wybrali się w drogę i nie bawiąc $z$ wielką wspaniałością i ozdobą już do Królewskiego Majestatu przy asystencji wielu książąt i panów już stanu duchownego, tak zakonnych jako i świeckich, w przytomności Najprzewielebniejszego Metropolity Suczawskiego i z nim zakonników wspomnianych, już przy zgromadzeniu niezliczonych różnego stanu ludzi do Żółkwi ciało świętego męczennika wprowadzone"ł2. Królem, jak widać, kierowała chęć osobistej identyfikacji za świętym - symbolem walki z Turkami. Zgodnie z przekazem kroniki klasztornej, utrzymanym w duchu apologetycznym, powracający po zwycięstwie nad Turkami Jan III pragnął oddać cześć szczątkom męczennika, uznawanego za symbol oporu wobec niewiernych. Czyżby zatem Jan wcześniej przemyśliwał nad pozyskaniem relikwii

39 I. Neculce, op. cit., s. 94.

40 W 1612 r. kanclerz i hetman wielki koronny Stanisław Żółkiewski (1547-1620) zezwolił wybudować w Żółkwi drewnianą cerkiew pod wezwaniem Narodzenia Chrystusa oraz erygować przy niej szkołę i szpital. Kolejni właściciele miasta, w tym kasztelanowa krakowska Zofia Teofila Sobieska (1607-1661) i jej syn Jan, pozwalali ludności rusińskiej na gromadzenie materiałów pod budowę nowej cerkwi. W 1684 r. Jan III wydał bractwu cerkiewnemu przywilej zezwalający mu na zbieranie funduszy pod budowę cerkwi murowanej. W maju $1691 \mathrm{r}$. wraz z pożarem nie wykończonej z zewnątrz ani od wewnątrz cerkwi miejskiej król postanowił o odbudowie świątyni i sprowadzeniu zakonu bazylianów. Inicjatywę w tej kwestii przypisuje się też biskupowi Józefowi Szumlańskiemu (1643-1708), który wykorzystał konflikt z miejscowym popem Polikarpem Łozińskim, oskarżonym o niemoralne prowadzenie się i oddał świątynię pod opiekę mnichom z Mołdawii oraz bazylianom, zapewne celem szerzenia idei unii religijnej na terenie Rusi Czerwonej. Szerzej: Opis jakim sposobem klasztor tutejszy żółkiewski O. O. Bazylianów nabył swój początek, Львівська національна наукова бібліотека України імені В. Стефаника (dalej: ЛННБУ), f. 3, op. 1, nr МВ-366, k. 2r-4v.; ЛННБУ, f. 3, op. 1, sygn. MВ-1413; Zbiorowy Halicko-Ruski Latopisiec od 1600-1700, wyd. A. C. Petruszewicz, Lwów 1874, 237, 244-246; В. Слободня, Украӥнські церкви Жовкви від найдавніших часів до середини XX cm., w: Жовква крізь століття, Видавничо-виробниче підприємство «Місіонер», t. 1, 2010, s. 221-223; М. Кубай, Дати і події в історії церкви Різдва Христового і монастиря отичів Василіан у Жовкві, w: ibidem, s. 88-94; M. Andrusiak, Józef Szumlański: pierwszy biskup unicki lwowski (1667-1708): zarys biograficzny, Lwów 1934, s. 103; A. Deruga, Biskup Józef Szumlański (1667-1708), Lwów 1935, s. 112; Т. Чухлиб, Львивский єпископ Йосиф Шумлянський - війсковий діяч та дипломат корони польской (60-ті роки XVII - початок XVIII cm.), „Україна: культурна спадщина, національна свідомість, державність" 2012, t. 23, s. 798-799.

${ }_{41}$ Szeroko na temat propagadny rodowej Sobieskich: A. Czarniecka, Nikt nie stucha mnie za życia ... Jan III Sobieski w walce z opozycyjna propaganda (1684-1696), Warszawa 2009; eadem, Przenikanie się sfery publicznej i prywatnej w życiu Jana III Sobieskiego i Marii Kazimiery, "Barok. Historia - Literatura - Sztuka”, R. 18, 2011, nr 2, s. 13-28; J. Pietrzak, Kult loretański w kręgu rodziny Sobieskich, „Studia Wilanowskie”, 2014, t. XXXI, s. $103-114$. O uroczystościach introdukcji relikwii: R. Mączyński, Nowożytne konfesje polskie. Artystyczne formy gloryfikacji grobów świętych i błogosławionych $w$ dawnej Rzeczypospolitej, Torun 2003; idem, Włoscy męczennicy pod niebem Pólnocy: rozważania nad problematyka importu i kultu relikwii świętych, w: Artyści włoscy w Polsce XV-XVIII wiek, red. J. A. Chrościcki, Warszawa 2004, s. 87-142; B. Manyś, Tajemnica relikwii św. Lucyda, czyli o obchodach okolicznościowych świąt sakralnych w Wilnie w czasach Augusta III. Przyczynek do badań, „Czas Przeszły”, 2016, t. 3 nr 1-2, s. 31-47.

42 Opis jakim sposobem..., ЛННБУ, f. 3, op. 1, sygn. МВ-366, k. 5r.-5v. 
świętego Jana? Takiego rozwiązania nie można odrzucić, jednak najważniejsze zdawało się być pragnienie posiadania przez monarchę namacalnego symbolu owej wiktorii, otoczonego aurą świętości i potrafiącego oddziaływać na umysły mas. Relikwie nikomu nieznanego świętego, lecz przypominające o jego żywocie naznaczonym przesłaniem wzywającym do walki z Turkami, idealnie nadawały się do tego celu.

Poza przesłankami heroiczno-propagandowymi, Janem kierowała praktyczna myśl nadania nowo powstałemu monastyrowi rangi ośrodka kultowego i miejsca szerzenia unii wśród prawosławnych ${ }^{43}$. Wraz ze sprowadzeniem relikwii do Żółkwi zaczęły ściągać rzesze pątników z terenów Mołdawii, Wołoszczyzny i Rusi. Ruch ten ulegał zapewne intensyfikacji wraz z nowinami o cudach uzyskanych za pośrednictwem świętego. W I694 r. żółkiewski monastyr nawiedził ojciec królowej Henryk de la Grange d'Arquien wraz z synem Anną Ludwikiem hrabią de Maligny. Zakonnicy zaprezentowali wówczas dostojnym gościom ciało świętego: „którym trumnę jego otwierano i twarz jego czarnokościstą prezentowano”44. Pobyt osobistości, jak i liczba organizowanych świąt oraz odpustów budowały sławę sanktuarium. Pielgrzymi przybywający do miasta zostawiali w nim, jak i w samym sanktuarium, znaczne sumy, co prowadziło do zwiększenia dochodów monastyru. Dzięki temu w krótkim czasie wystawiono nową, murowaną cerkiew miejską i powstało bractwo cerkiewne ${ }^{45}$. W wymiarze topograficznym i symbolicznym zarazem cerkiew wraz z monastyrem wypełniły niezagospodarowaną dotąd przestrzeń na szlaku wiodącym od kolegiaty rzymskokatolickiej po ratusz i pałac rodziny królewskiej, stając się w sensie ideowym kolejnym pomnikiem chwały Jana III ${ }^{46}$.

Od czasu przybycia do Żółkwi metropolitę Dozyteusza określić można mianem kustosza i strażnika ciała świętego oraz reszty mołdawskich skarbów. Metropolita podtrzymywał kontakt z patriarchą moskiewskim i Wszechrusi Joachimem II (I62I-I690), jednak informacje, jakoby zmarł w Moskwie, są nieprawdziwe ${ }^{47}$. Duchowny dokonał swego żywota w Żółkwi I3 grudnia I693 r., o czym świadczy zarówno napis na blasze z portretu trumiennego ${ }^{48}$, jak i wpis w „Pomianniku” lwowskiego bractwa stauropigialnego ${ }^{49}$. Warto zwrócić przy tej okazji uwagę na nowe źródła opisujące uroczystości pogrzebowe duchownego. W końcu I693 r., w cerkwi bazyliańskiej w Żółkwi, odbyła się pompa funeralna. Jeden z rachunków stwierdza, że: „na dzień pogrzebu tegoż ojca metropolity we Lwowie kupowano sukno,

\footnotetext{
43 W. Bondyra, Greckokatolickie fundacje szlacheckie na Rusi Czerwonej w czasach saskich, „Res Historica”, 2004, z. 17, s. 63-64.

44 K. Sarnecki, Pamiętniki z czasów Jana Sobieskiego, t. 1, Diariusz 1690-1695, wyd. J. Woliński, Wrocław 2010, s. 145 .

45 Б. Лазорак, Духовна феміда і иеерковне братство Різдва Христового в Жовкві (друга половина ХVII XVIII cm.), „Історія релігій в Україні”, t. 1, 2010, s. 98-106; idem, Інституційне оформлення иерковного братства Різдва Христового в Жовкві (XVII - ХVIII ст.) w: Жовква крізь століття..., t. 1, 2010, s. 106-132; idem, Внутрішне середовище иерковного братство Різдва Христового в Жовкві та його правові взаемини з васнліанами в другої половини XVII-XVIII cm., w: ibidem, t. 2, 2012, s. 109-134.

46 Szerzej na ten temat: J. T. Petrus, Kościoły i klasztory Żółkwi. Materiały do dziejów sztuki sakralnej na ziemiach wschodnich dawnej Rzeczypospolitej, cz. 1, Kościoły i klasztory rzymskokatolickie dawnego województwa ruskiego, Kraków 1994; J. Macyszyn, Żółkiewska kolegiata - pomnik chwały żotnierskiej, w: Biblioteka epoki nowożytnej, t. 2, Sobieski wokól spisków i konfederacji, red. M. Nagielski, Warszawa 2015, s. 187-203.

${ }_{47}$ M. Sokołowski, op. cit., s. 25-28; Ş. Ciobanu, Contribuţiuni privitoare la originea şi moartea mitropolitului Moldovei Dosofteiu, Bucureşti 1920, s. 14-16.

48 M. Gębarowicz, Szkice z historii sztuki XVII w., Toruń 1960, s. 261-266.

49 M. Sokołowski, op. cit., s. 29.
} 
za które Pan Administrator wydał 600 złotych" ${ }^{\circ}$. Kazanie pogrzebowe wygłosił biskup lwowski Józef Szumlański. Inne zachowane rachunki określają, że: „za świece na pogrzeb ojca metropolity wydano 585 złotych”5I oraz że: „na pogrzeb ojca metropolity suczawskiego wydano na obraz - IOo złotych" ${ }^{2}$. Z kolei: „,na farby do katafalku i robotę trumny” $5_{3}$ wydano złotych 26. Wykonanie portretu trumiennego oraz projektu castrum doloris zlecono Tomaszowi Wiesiołowiczowi lub Jerzemu Eleuterowi Szymonowiczowi-Siemiginowskiemu (I660-I7II) ${ }^{54}$. Król Jan III wziął na siebie także ciężar utrzymania towarzyszących metropolicie mnichów, którym przeznaczył I 000 złotych polskich ${ }^{55}$. W tym miejscu podać należy, że monarcha otoczył też opieką brata metropolity, który „z ordynacji Króla Jmści wydane przez J.W. JM Pana Podskarbiego Wielkiego Księstwa Litewskiego [tj. Benedykta Pawła Sapiehy - przyp. J.P.] do mnie asygnacje na wydanie strawnych pieniędzy, co tydzień po złotych Io a to od d. I2 Aprilis I694 roku wydał złotych 250"56. Królowa Maria Kazimiera żaliła się kasztelanowi wołyńskiemu Stefanowi Zahorowskiemu (?-I696), iż „,brata nieboszczyka Metropolity Suczawskiego pewną dawał król pensję, którego z własnego naszego żywić musimy skarbu' ${ }^{57}$. Są to informacje wielce cenne, ponieważ brat metropolity nie był do tej pory w ogóle wzmiankowany.

$$
* * *
$$

Materialna spuścizna po metropolicie mołdawskim składała się z relikwii św. Jana Nowego wraz z przedmiotami zdeponowanymi w relikwiarzu ${ }^{58}$, aparatów cerkiewnych oraz insygniów metropolitalnych, aktów i dokumentów należących do metropolii mołdawskiej oraz - co pominął Marian Sokołowski - kosztowności zrabowanych przez bliżej nieznanego towarzysza chorągwi husarskiej podczas wymarszu wojsk polskich z Jass, a następnie zwróconych Dozyteuszowi ${ }^{59}$. Jeszcze przed śmiercią Dozytusza hospodar Konstanty Kanetmir skierował

50 Ekspensa pieniężne za sumę wydanych i oddanych do rachunków IchMsciów Kommisarzów JKMści Miłościwego Pana per anni 1685, 1686, 1687, 1689, 1690, 1691, 1692. Rachunek kosztów ad anni 1694 i zakończonych 21 Martii Anii 1695, НГАБ, f. 694, op. 2, nr 9995, k. 92r.

51 НГАБ, f. 694, op. 2, nr 2457, k. 108r.

52 Ekspensa pieniężne za sumę wydanych..., НГАБ, f. 694, op. 2, nr 9995, k. 92r.

53 Ibidem.

54 T. Mańkowski, Mecenat Jana III w Żótkwi, „Prace Komisji Historii Sztuki” 1948, t. 9, s. 145-146; M. Gębarowicz, op. cit., s. 265-269.

55 НГАБ, f. 694, op. 2, nr 2457, k. 44v.

56 Ekspensa Pieniężna w Roku 1695 wydawana rzetelnie przy tym i dowodnie do Rachunków zebrana, НГАБ, f. 694 , op. 2, nr 2499, k. 36r.

57 Maria Kazimiera d'Arquien Sobieska do N. N. Zahorowskiego, b. m., 17 V 1695, Archiwum Główne Akt Dawnych w Warszawie (dalej: AGAD), Archiwum Komierowskich, sygn. 76/101, s. 273.

58 Zgodnie z opisem akt wizytacyjnych z 1740 r. i 1747 r. relikwiarz w kształcie sarkofagu, obity srebrną blachą, znajdował się w ołtarzu po prawej stronie od ikonostasu: Націона́льний музе́й у Льво́ві. Науко́во-худо́жній фонд митрополи́та Андре́я Шепти́цького, sygn. 17, k. 157v.; Visitatio Residentia Żółkiviensis Ecclesia Suppelectilis tum Ecclesiastica tum Domestica Die 31 Octobris 1747 A. expedita speracta, Центральний державний історичний архів України, м. Львів, fond 201, opis 4, sprawa 529, k. 65r. (za informację i i udostępnienie obu dokumentów pragnę złożyć podziękowania dr hab. Beacie Lorens prof. UR z Uniwersytetu Rzeszowskiego).

59 Biblioteka Czartoryskich w Krakowie, sygn. 752, s. 304v.-306v; Opis jakim sposobem..., ЛННБУ, f. 3, ор. 1, sygn. MB-366, k. 19v.-20r. Do zrabowanych dóbr należały m.in. mitra biskupia na zielonym aksamicie zwieńczona krzyżem, wykończona złotą i srebrną nicią z wizerunkami Salwatora, św. Jana, Najświętszej Marii Panny, sadzona perłami i drogimi kamieniami, ikona Najświętszej Marii Panny z Chrystusem, welum z wyszywanymi postaciami 
do duchownego odezwę z prośbą o zwrot relikwii6o. W końcu I693 r., kiedy metropolita zmarł, zabiegi o oddanie relikwii przybrały na sile. W I699 r., po odzyskaniu przez Polaków Kamieńca Podolskiego, syn hospodara Konstantego Kantemira Antioch (I708-I744) prosił, acz bezskutecznie, Augusta II - przeciwnika królewiczów Sobieskich - o oddanie relikwii ${ }^{\text {II }}$. W I709 r. archimandryta klasztoru w Roman, Pachomiusz, chcąc wykorzystać pobyt cara Piotra I w Żółkwi, ponowił apel o wydanie ciała św. Jana Nowego ${ }^{62}$. Prawosławny monarcha nie okazał jednak swej łaski.

Przez całą pierwszą połowę XVIII w. kult św. Jana Nowego w Żółkwi kwitł, przynosząc klasztorowi bazyliańskiemu w Żółkwi wysokie dochody ${ }^{63}$. Potwierdzeniem znaczenia sanktuarium i czci, jaką cieszył się mołdawski święty, był przywilej królewicza Konstantego Sobieskiego z 20 lutego I726 r., w którym zalecał zakonnikom regularne odprawianie służby Bożej przed relikwiami świętego ${ }^{64}$. Po 1740 r., kiedy właścicielami Żółkwi stali się Radziwiłłowie, do rozsławienia kultu świętego Jana Nowego przyczyniły się także dwie inne okoliczności. Za pierwszą uznać należy wieści o licznych uzdrowieniach, jakich dostąpili wysoko urodzeni za wstawiennictwem świętego. Kronika klasztoru żółkiewskiego odnotowała m.in. uleczenie Marii Karoliny z Sobieskich księżnej de Bouillon (I697-I740) z palpitacji serca w I739 r., kasztelanki oświęcimskiej Walerii z Szembeków Branickiej (I7I2-I78) w I750 r. czy wojewody wileńskiego i hetmana wielkiego litewskiego Michała Kazimierza Radziwiłła „Rybeńko” (I702-I762) w I750 r., który „uczuwszy ból w gębie, to jest w lewej szczęce na dole, a chorując na ten ból nie mało nie dwa miesiące, a potem gdy ślinogorz przez cały miesiąc go trapiła i gorączka wielka wzmogła się, krew z nogi puszczono w niebezpieczeństwie życia został. [...] w tym ofiarował się do Sługi Bożego Jana Suczawskiego w klasztorze OO. Bazylianów a kazawszy przynieść tuwalię, która twarz świętego okryła, jak i prędko twarz obwiązał [...] i do pierwszego zdrowia przyszedłszy, ten cud świętemu Janowi Męczennikowi, wychwalając Imię Pańskie pod przysięgą przyznał"65. Zapewne to wydarzenie przyczyniło się w I753 r. do decyzji księcia o podniesieniu klasztoru żółkiewskiego do rangi archimandrii ${ }^{66}$, to jest zwierzchniego względem klasztorów bazyliańskich na terenie eparchii przemyskiej. Postanowienie to traktować należy jako drugą okoliczność mającą wpływ na utwierdzenie kultu świętego Jana Nowego ${ }^{67}$. Argumentem

\footnotetext{
Chrystusa i aniołów, srebrna kadzielnica, dalmatyka biskupia, antependium z czerwonego karmazynu, zasłonka adamaszkowa, całun na trumnę św. Jana Nowego.

60 D. Scărlătescu, Cărtuari Români în Galiţia. Pe urmele tezaurului mitropolitan al Moldovei, w: Românii din afara graniţlor ţării. Iaşi-Cernăuţi: legături istorice, red. I. Pruteanu-Isăcescu, A. Zub, Iaşi-Cernăuţi-Herţa-Edineț, 2012, s. 27.

61 M. Sokołowski, op. cit., s. 34.

62 D. Scărlătescu, op. cit., s. 27.

63 Wspomnieć należy o legatach zapisywanych klasztorowi przez mieszczan żółkiewskich, odnotowanych m.in. w testamencie Paraskiewi Oleksichy z maja 1695 r. (Наукова бібліотека Львівського національного університету імені Івана Франка (dalej: НБЛНУ), Księga miejska sądu wójtowsko-ławniczego miasta królewskiego Żółkwi 1693-1695, sygn. 604.III, k. 67v.) oraz testamencie Katarzyny Percychy z 1702 r. (НБЛНУ, Księga miejska sądu wójtowsko-ławniczego miasta królewskiego Żółkwi 1702-1705, sygn. 605.III, k. 25r.).

64 НГАБ, f. 694, op. 4, nr 1003, k. 249r.

65 Opis jakim sposobem..., ЛННБУ, f. 3, op. 1, sygn. МВ-366, k. 10v.-11r.

${ }_{66}$ Ibidem, k. 30r.-33r.; ЛННБУ, f. 3, op. 1, sygn. МВ-1412; AGAD, Archiwum Warszawskie Radziwiłłów, dz. V, sygn. 18146, s. 15; B. Lorens, Bazylianie prowincji koronnej w latach 1743-1780, Rzeszów 2014, s. 66.

${ }^{67}$ Michał Kazimierz Radziwiłł poprzez rozwinięcie kultu św. Jana Suczawskiego pragnął także nawiązać do królewskiego splendoru Jana III Sobieskiego, z którym był spokrewniony poprzez swoją babkę - Katarzynę z Sobie-
} 
dodatkowo przemawiającym za takim sądem jest list generała zakonu bazylianów Herakliusza Lisańskiego (I702-I77I) z I754 r. do księcia z prośbą o uchronienie klasztoru przed zaborczymi zakusami ze strony kleru rzymskokatolickiego, w którym nadawca wspominał, że ,żółkiewska cerkiew od Najjaśniejszego Dziada W. X. Mści Niezwyciężonego Króla Jmci Jana III i dla krzewienia kultu świętego Jana Soczawskiego istnieje"68. Zakonnicy, wdzięczni księciu za ekspediowane fundusze na rzecz świątyni ${ }^{69}$ oraz książęcą protekcję, odprawiali za swego dobrodzieja liczne nabożeństwa w obecności relikwii świętego i przekazywali w imieniu męczennika swe błogosławieństwo ${ }^{70}$. Na koniec warto jeszcze wspomnieć, że przeor bazylianów żółkiewskich Jozafat Wysocki (?-I773) dążył, za pośrednictwem księcia Radziwiłła oraz króla polskiego Augusta III, do wyjednania w Stolicy Apostolskiej liturgicznego wspomnienia świętego Jana jako męczennika za wiarę ${ }^{71}$.

Wraz z upadkiem Żółkwi, jako ośrodka miejskiego pod rządami książąt Radziwiłłów i ogólnym kryzysem państwowości polskiej w 1769 r., Mołdawianie wysłali specjalną petycję do carycy Katarzyny II z prośbą o zwrot relikwii. Ich wysiłki po raz kolejny spełzły na niczym ${ }^{72}$. Dopiero w 1783 r., kiedy Żółkiew już od dekady znajdowała się granicach Galicji w ramach monarchii habsburskiej, pojawiły się widoki na przełom w sprawie. Cesarz Józef II, chcąc podnieść znaczenie dawnej Mołdawii (Bukowiny) jako jednej z prowincji jego władztwa, pozytywnie ustosunkował się do prośby biskupa Radowiec, Dozytusza Herescu (ok. I7Io-I789), i nakazał zwrot relikwii św. Jana Nowego do Jass ${ }^{73}$. 28 czerwca I783 r. o północy cesarski komisarz rządowy polecił żołnierzom wynieść relikwie z klasztoru bazylianów w Żółkwi i odtransportować specjalnie przygotowanym wozem do Suczawy ${ }^{74}$. Zakonnicy, przypuszczając, jaki los może spotkać relikwie, postanowili zatrzymać rękę św. Jana Nowego oraz część kosztowności przechowywanych w relikwiarzu. Mołdawianie odzyskali ponadto bogate atłasowe przykrywadła trumienne haftowane złotem i nabijane rubinami oraz perłami, natomiast bazylianie zatrzymali srebrną kadzielnicę, ewangeliarz

\footnotetext{
skich Radziwiłłową. Sąd taki można wysnuć na podstawie aktu fundacyjnego archimadrii żółkiewskiej, w którym Radziwiłł przypominał o sprowadzeniu relikwii św. Jana przez króla Jana III oraz w oparciu o hagiografię św. Jana, przechowywaną wśród rękopisów bibliotecznych Radziwiłłów w Nieświeżu. W tym drugim dokumencie widnieje dopisek o sprowadzeniu relikwii męczennika do Polski przez Sobieskiego: Akt fundacyjny archimandrii żółkiewskiej przez Michała Kazimierza Radziwiłła "Rybeńko", na zamku żółkiewskim, 3 II 1753, Zbiory Aleksandra Czołowskiego [dalej: Zb. Czoł.], sygn. 91, s. 23-25; Męczeństwo S. Jana Nowego rzeczonego Soczawskiego, który był męczony w Białogradzie etc., AGAD, AR, Rękopisy Biblioteczne, sygn. 244, s. 1-4.

68 Herakliusz Lisański do Michała Kazimierza Radziwiłła „Rybeńko”, Torokanie 14 XII 1754, AGAD, AR, dz. VIII, sygn. 672, s. 1-2.

69 Zakonnicy, na podstawie aktu o fundacji archimandrii, otrzymywali wypłatę 700 złotych polskich dwukrotnie, w Boże Narodzenie i w dzień św. Jana Chrzciciela (24 czerwca). Archimandryta ponadto, aż do śmierci księcia w 1762 roku, dostawał sumę 24906 złotych polskich: Tabela Onerum na dobrach żółkiewskich i pomorzańskich wykonnotowana 8 VIII 1762, AGAD, AR, dz. XI, sygn. 149, s. 42.

70 Jozafat Wysocki do M. K. Radziwiłła „Rybeńko”, Żółkiew, 14 IV 1741, AGAD, AR, dz. V, sygn. 18146, s. 1-2;

71 J. Wysocki do M. K. Radziwiłła „Rybeńko”, Żółkiew, 2 X 1746, AGAD, AR, dz. V, sygn. 18146, s. 5.

72 Ş. Dinulescu, op. cit., s. 477-479; D. Scărlătescu, op. cit., s. 31-33.

73 Opis jakim sposobem..., ЛННБУ, f. 3, op. 1, sygn. МВ-366, k. 35r-36r.

74 Copia Decreti Gubernialis Regni Galiciae et Lodomeriae respecta Corporis Divini Ioannes de Soczawa Ord. Sanctii Basilii Magni Conventis Żółkieviensis, AGAD, AR, dz. VIII, sygn. 672, s. 8-9; S. Fl. Marian, Sântul Ioan cel Nou de la Suceava. Schiţa istorică, Bucureşti 1895, s. 110; M. Sokołowski, op. cit., s. 65-66.
} 
w złotej oprawie, antependium, haftowany złotą nitką obraz Bogarodzicy i obszytą złotem płaszczenicę z czerwonego aksamitu ${ }^{75}$.

Klasztor od czasu utraty cudownych relikwii stracił swoje znaczenie jako ośrodek kultu. Zdaniem autora kroniki klasztornej, „gdy rano piechota ustąpiła, zaraz się po mieście i wsiach wieść rozniosła, że Mołdawianie św. Jana męczennika już wzięli. W całym mieście Żółkwi była żałoba, lament i płacz za świętym Janem Soczawskim Męczennikiem. Płakali nie tylko chrześcijanie, ale nawet Żydowie, bo od tego czasu ustały liczne odpusty i dochody" ${ }^{\prime 6}$. W I784 r. z misją do Wiednia wyruszył bazylianin ojciec Hieronim (Eliasz) Strzelecki (I732/I733-I804), który prosił - w imieniu swoim i papieża Piusa VI - o darowanie relikwii św. Parteniusza (rzymskiego legionisty, który poniósł męczeńską śmierć w 250 r. n.e.), spoczywających w klasztorze klarysek ${ }^{77}$. We wrześniu tegoż roku, z polecenia cesarza Józefa II, arcybiskup Wiednia Christoph Anthon Graf von Migazzi (I704-I8I3) przekazał relikwie wraz ze świadectwem ich autentyczności do Żółkwi ${ }^{78}$. Cesarska zgoda posiadała bardzo poważny wydźwięk symboliczny. Święty Parteniusz uznawany był za niebiańskiego opiekuna stolicy Cesarstwa, a tradycja przypisywała mu interwencję w czasie oblężenia Wiednia przez Turków w I683 r. Umieszczenie szczątek męczennika w Żółkwi - kojarzonej z osobą rzeczywistego autora wiktorii wiedeńskiej i pogromcy nieprzyjaciół wiary, Jana III Sobieskiego - pozwoliło cesarzowi Józefowi na utożsamienie się z polskim monarchą oraz na ogłoszenie się przywódcą krucjaty antytureckiej ${ }^{79}$. Decyzja ta dla klasztoru, poza przywróceniem mu statusu miejsca pielgrzymkowego, była bardzo korzystna, bowiem oznaczała oddalenie groźby kasaty ${ }^{80}$. Na początku kolejnego wieku żółkiewski klasztor bazylianów

\footnotetext{
75 Regestr Sreber i Apparatów, które się pobrały po śmierci Nieboszczyka Oyca Metropolity Soczawskiego, oddały Bractwu do Cerkwi Murowaney, Mieyskiey Żółkiewskiey, i do Ciała Świętego Jana Soczawskiego, z Skarbu Iego Królewskiey Mości, spisany w Żółkwi Die Undecima Februarii Millesimo Sexcentesimo Nonagesimo Quarto Anno, w: M. Sokołowski, op. cit., s. 42-44.

76 Opis jakim sposobem..., ЛННБУ, f. 3, op. 1, sygn. МВ-366, k. 35v.

77 Relikwie św. Parteniusza zostały sprowadzone do Wiednia w 1666 r. za zgodą papieża Aleksandra VII i ofiarowane następnie przez cesarza Leopolda I ksieni klasztoru klarysek Marii Bibianie hr. Breuner. Rok później arcybiskup Wiednia Filip Fryderyk Breuner zezwolił na kult publiczny męczennika wraz z wystawieniem jego relikwii w trzecią niedzielę września: Opis jakim sposobem..., ЛННБУ, f. 3, op. 1, sygn. МВ-366, k. 40r-v.; ЛННБУ, f. 3, op. 1, nr MB-1411.

78 ЛННБУ, f. 3, op. 1, nr МВ-1414.

79 Szerzej na ten temat: A. Sommer-Mathias, Trzysta lat króla Jana III Sobieskiego na wiedeńskich scenach. Pamięć o ,,Turkach”, medialna inscenizacja i propaganda polityczna [Muzeum Pałac Jana III w Wilanowie,http:// www.wilanowpalac.art.pl/trzysta_lat_krola_jana_iii_sobieskiego_na_wiedenskich_scenach_pamiec_o_turkach medialna_inscenizacja_i_propaganda_polityczna.html, dostęp z $0 \overline{4}$ VII 2017]; J. Pietrzak, Erinnerungen an die „Victoria” Die Jahrestage des Entsatzes von Wien 1683 als Propagandainstrument der Regierenden, „Historie. Jahrbuch des Zentrums für Historische Forschung Berlin der Polnischen Akademie der Wissenschaften”, Folge 10, 2016, s. 50-51.

${ }^{80}$ Visitatio Generalis Ecclesiae Parochialis in Civitate Żółkiew die 2da Octobris 1792 Anno expedita, Archiwum Państwowe w Przemyślu, Archiwum Biskupstwa Greckokatolickiego w Przemyślu, sygn. 327, k. 9r.-11r. O kasatach klasztorów bazyliańskich w Galicji w XVIII w.: B. Lorens, Uniccy biskupi przemyscy a męskie klasztory bazyliańskie w latach 1691-1793, w: Klasztor w Kościele średniowiecznym i nowożytnym, red. M. Derwich, A. Pobóg-Lenartowicz, Warszawa 2010, s. 203-217; eadem, Sytuacja gospodarcza monasterów bazyliańskich w Galicji u progu kasat józefińskich oraz losy ich majątku po kasacie. Zarys problemu, w: Klasztor w gospodarce średniowiecznej i nowożytnej, red. M. Derwich, Wrocław 2013, s. 623-643; eadem, Bazylianie w Galicji wobec działań kasacyjnych w latach 1772-1792, w: Kasaty klasztorów na obszarze dawnej Rzeczypospolitej Obojga Narodów i na Śląsku na tle procesów sekularyzacyjnych w Europie, t. 1, Geneza kasaty na ziemiach zaborów austriackiego i rosyjskiego, red. M. Derwich, Wrocław 2015, s. 215-232.
} 
zdążył odbudować swoją pozycję, co sprawiło, że na nowo stał się znanym sanktuarium oraz ośrodkiem działalności drukarskiej i misyjnej zakonu ${ }^{8 \mathrm{I}}$.

Kolejną część schedy po Dozytueszu stanowiły paramenty liturgiczne oraz insygnia jego władzy jako metropolity Mołdawii ${ }^{82}$. Po jego przybyciu do Stryja we wrześniu I686 r. wszystkie kosztowności zostały złożone na zamku i zinwentaryzowane w obecności biskupa przemyskiego Jana Stanisława Zbąskiego (I639-I697), stolnika ziemskiego buskiego i administratora stryjskiego Aleksandra Wyszyńskiego (?-I687) oraz samego Dozyteusza ${ }^{83}$ Sądzić można, że jeszcze pod koniec życia władyki przedmioty te zostały przejęte przez króla Jana III i włączone do skarbca mieszczącego się na zamku żółkiewskim. Wyznaczony w I694 r., po śmierci Dozyteusza, na tymczasowego administratora metropolii mołdawskiej, biskup Józef Szumlański pozostawił dla siebie najcenniejsze spośród nich, resztę przekazując na użytek cerkwi w Żółkwi, katedry św. Jura we Lwowie oraz innych świątyń ${ }^{84}$. Część rzeczy, która znajdowała się w skarbcu żółkiewskim została po śmierci Jana III w I696 r. przewieziona do Lwowa i złożona w kamienicy królewskiej na Starym Rynku. Tam w obecności królowej Marii Kazimiery, hetmana Jabłonowskiego, biskupa Szumlańskiego oraz mnicha mołdawskiego i opata bazylianów żółkiewskich Adriana wszystkie przedmioty zostały opisane i na nowo włączone do skarbca Sobieskich ${ }^{85}$. Możliwe, że część przedmiotów została wywieziona do Rzymu przez królową w i698 r. lub stały się własnością Radziwiłłów i zostały odesłane do ich skarbca w Nieświeżu.

Ostatnim komponentem wchodzącym w skład dziedzictwa Dozyteusza były dokumenty z archiwum metropolii mołdawskiej. W sumie 396 rękopisów obejmujących lata I403-I693 zostało dokładnie zinwentaryzowanych dopiero w styczniu I783 r. przez kasjera miejskiego Lwowa Jana Anastazego Monawerdę na rozkaz namiestnictwa cesarskiego ${ }^{86}$. Następcy Sobieskich, Radziwiłłowie, w latach I740-I783 przewieźli część dokumentów do Nieświeża. W wyniku podziału przeprowadzonego przez archiwistów przed II wojną światową i po przeniesieniu części manuskryptów do Warszawy doszło także do przemieszczenia dokumentów metropolii mołdawskiej. Po II wojnie światowej część warszawska archiwaliów została włączona do Archiwum Głównego Akt Dawnych (zespół 354) ${ }^{87}$, natomiast zbiory

${ }^{81}$ Zagadnieniom tym niemal w całości poświęcone są archiwalia zdeponowane w Centralnym Państwowym Archiwum Historycznym Ukrainy we Lwowie (fond 684, opis 1, sprawa 413) oraz Lwowskiej Naukowej Narodowej Bibliotece Ukrainy im. Wasyla Stefanyka we Lwowie (fond 3, opis 1, nr MB-1430)

82 Do nich zaliczyć należy szaty liturgiczne (omofory, sakosy, narakwice, ipolice), paramenty liturgiczne (kadzielnice, łyżeczki, cyboria, ewangeliarze, krzyże), oznaki władzy biskupiej (mitry, pastorały, enkolpiony) oraz ikony i relikwiarze.

83 BCz., sygn. 752, k. 287r.

84 Regestr rzeczy które JM Ociec Episkop wziął do Kathedry Lwowskiej, y do innych Cerkwi ubogich, w dyspozycyą Swoie, po Nieboszczyku Oicu Metropolicie Soczawskim w Żółkwi, z Skarbca Króla Iegomosci, d. 11 Februarii 1694, AGAD, Zb. Czoł., sygn. 394, s. 23-24. Jak wynika z zachowanych dokumentów, Szumlański otrzymał nowe insygnia biskupie, $\mathrm{w}$ tym pastorał wykonany ze srebra przetopionego z lampy z kościoła w Złoczowie wart 175 złotych polskich: Expensa Pieniężne w Roku 1695 wydawane przy tym i dowodnie do Rachunków zebrane, НГАБ, f. 694, op. 2, nr 2499, k. 36r.

85 M. Sokołowski, op. cit., s. 31-32.

86 D. Scărlătescu, op. cit., s. 33. Sokołowski podaje liczbę 223 dokumentów, conf. M. Sokołowski, op. cit., s. 35. Pełen spis został ogłoszony: Gh. Popovici, Index Zolkiewiensis, „Candela”, t. 3 (1884) i t. 4 (1885).

87 Na ten temat szeroko: E. Barwiński, Archiwum ks. Radziwiłtów w Nieświeżu. Rys jego historii i sprawozdanie z poszukiwań, „Archiwum Komisji Historycznej PAU”, t. 11, Kraków 1909, s. 1-10; R. Jankowski, Archiwiści $i$ instrukcje archiwalne napisane dla nich $w$ Archiwum Głównym Radziwiłlów w Nieświeżu, „Archiwista Polski”, R. 5, 2000, nr 2 (18), s. 34-40; idem, Burzliwe losy Archiwum Radziwitłów z Nieświeża od XV w. do 1838 r., „Mi- 
nieświeskie znalazły się Narodowym Archiwum Historycznym Białorusi w Mińsku ${ }^{88}$. Warto także dodać, że dokumenty metropolii odnaleźć można w zespole Zbiór Dokumentów Pergaminowych AGAD (zespół I) ${ }^{89}$.

Podsumowując rozważania, należy zwrócić uwagę, że emigracja Dozyteusza i oddanie się w protekcję polskiego króla stało się punktem zwrotnym w kontaktach polsko-mołdawskich. Jan III oskarżany był o zabór narodowych świętości, z których najcenniejsze wydawały się relikwie św. Jana Nowego. Życie na obczyźnie metropolity, który obawiał się powrotu do Jass i zemsty ze strony hospodara Kantemira, określić można jako ustabilizowane. Jego śmierć pozwoliła królowi Polski na mianowanie Józefa Szumlańskiego tymczasowym administratorem metropolii ze stolicą we Lwowie. Decyzja ta umożliwiła następnie Janowi III ingerencję w stosunki wyznaniowe hospodarstwa, tym bardziej, że Szumlański otwarcie sympatyzował z unitami, a w I700 r. oficjalnie włączył eparchię lwowską do struktur Kościoła greckokatolickiego. Sądzić można, że królowi zależało na rozpoczęciu misji chrystianizacyjnej w Mołdawii i stopniowym przeciągnięciu prawosławnych do Kościoła rzymskokatolickiego ${ }^{90}$. Zaryzykować można nawet pogląd, że Jan po dwóch porażkach militarnych w Mołdawii dążył do przejęcia kontroli nad nią, wykorzystując do tego celu nie tylko stronnictwo propolskie, ale i pośrednictwo Kościoła kształtującego poglądy ludu. Fiasko trzeciej już kampanii wojennej w Mołdawii w I69I r., która ruszyła z zamiarem odbicia Kamieńca, a w rzeczywistości podboju hospodarstwa i oparcia granicy Rzeczypospolitej o Dunaj, nadszarpnęło autorytet monarchy ${ }^{91}$. Niezależnie jednak od planów politycznych, militarnych i dynastycznych snutych przez Jana III stwierdzić należy, że przejęcie przez niego materialnych tworów kultury - w tym manuskryptów i kosztowności, często posiadających średniowieczną metrykę - odcięło Mołdawian na długie lata od obcowania z nimi i opóźniło proces kształtowania ich tożsamości narodowej.

scellanea Historico-Archivistica" (dalej: MHA), 2000, t. 11, s. 35-68; idem, Prace inwentaryzacyjne w Archiwum Głównym Radziwiłlów w Nieświeżu do 1945 r., „Archiwista Polski”, R. 5, 2000, nr 3(19), s. 43-55; idem, Archiwum Radziwiłtów z Nieświeża od 1838 r. do XX w. MHA, 2001, t. 13, s. 131-168; T. Zielińska, Archiwa Radziwiłlów i ich twórcy, „Archeion”, 1978, t. 66, s. 105-129; eadem, Archiwalia różnych linii rodu Radziwiłlów w polskich zbiorach publicznych, MHA, 1997, t. 8, s. 107-113; eadem; Archiwa wielkich rodów Rzeczypospolitej dziedzictwem narodów Europy Środkowej $i$ Wschodniej, „Archiwista Polski”, 1999, nr 2 (14), s. 33-40.

88 E. Szymczuk, Kwerenda archiwaliów w Mińsku, „Archeion”, 1997, t. 97, s. 408-412; A. K. Gołubowicz, Dokumenty i materiały rodu Radziwiłtów w Narodowym Archiwum Historycznym Białorusi w Mińsku, MHA, 1997, t. 8, s. 93-97; E. Bagińska, Fond Radziwiłłów w Państwowym Archiwum Historycznym Białorusi w Mińsku, „Białostocczyzna", R. 49, 1998, z. 1, s. 58-63.

89 W. Constantinov, Primul document original descoperit din arhiva mitropoliei Moldovei înstrăinată la 1686 , „Arhiva Moldaviae”, 2010, t. 2, s. 189-192; idem, Noi documente originale din arhiva mitropoliei Moldovei înstrăinată la 1686 şi o istorie a mănăstirii Putna într-un pergament din secolul al XVIII-lea, w: Retrospecții medievale. In honorem Professoris emeriti Ioan Caproșu, ed. Victor Spinei, Laurențiu Rădvan, Arcadie M. Bodale, Iași, Editura U medievale. In honorem Professoris emeriti Ioan Caproșu, ed. V. Spinei, L. Rădvan, A. M. Bodale, Iași 2014, S. 141-154.

90 D. Tollet, La reconquête catholique en Moldavie sous le règne de Jean III Sobieski, w: L'Europa centro-orientale..., s. 193-215.

91 P. Smolarek, Kampania mołdawska Jana III roku 1691, Oświęcim 2015. 
The stay of the Moldavian metropolitan Dositheos in Zhovkva in 1686-1693, his legacy, and the issue of the veneration of St. John the New's (Suceava) cult until the end of the $18^{\text {th }}$ century

\section{Abstract}

The article presents the outcome of the expedition of John III Sobieski to Moldavia in I686. In addition to political and military aspects, the protection of metropolitan Dositheos and the accompanying monks is one of the most important effects of the retreat of the Polish-Lithuanian army from Iasi. The clergyman, leaving the Principality of Moldavia (Hospodarstwo), took with him, besides the valuable tokens of his authority, liturgical apparatus and metropolitan archives, also the relics of St. John the New lodged in a silver sarcophagus, constituting the national sanctity of Moldavians. The rest of the article discusses the details of the metropolitan's stay in Stryi and Zhovkva until his death in I693, the development of the cult of St. John the New in the context of the construction of royal splendour, the efforts on Moldavian side to get back the remains of the saint and the revindication of the relics in 1783 .

Keywords: Basilian monks, Iasi, Moldavia, relics, the Sobieski

\section{BIBLIOGRAFIA}

\section{Źródła archiwalne}

Archiwum Główne Akt Dawnych w Warszawie:

- Archiwum Komierowskich, sygn. 76/IOI.

- Archiwum Warszawskie Radziwiłłów, dz. V, sygn. I8I46; dz. VIII, sygn. 672; dz. XI, sygn. I49.

- Zbiory Aleksandra Czołowskiego, sygn. 9I, 394.

Biblioteka Czartoryskich w Krakowie, sygn. 752.

Biblioteka Kórnicka Polskiej Akademii Nauk w Kórniku, sygn. I559.

Biblioteka Polskiej Akademii Umiejętności - Polskiej Akademii Nauk w Krakowie:

- $\quad$ Teki Cieszkowskiego, sygn. 8700.

- $\quad$ Teki Rzymskie, sygn. 8442, t. I02.

Центральний державний історичний архів України, м. Львів:

- $\quad$ fond 20I, opis 4, sprawa 529.

Львівська національна наукова бібліотека України імені В. Стефаника (Lwowska Narodowa Naukowa Biblioteka Ukrainy im. W. Stefanyka we Lwowie):

- $\quad$ fond 3 (Materiały Bazyliańskie): op. I, nr MB-366, MB-I4II, MB-I4I2, MB-I4I3, MB-I430. Націона́льний музе́й у Льво́ві. Науко́во-худо́жній фонд митрополи́та Андре́я Шепти́цького, sygn. I7.

Нацыянальны гістарычны архіў Беларусі (Narodowe Archiwum Historyczne Białorusi w Mińsku):

- fond 694, (Archiwum Książąt Radziwiłów), op. 2, nr 2457, 2460, 2499, 9995; op. 4, nr I004.

- $\quad$ fond 695 (Archiwum Sobieskich z Oławy), op. I, nr I29.

Наукова бібліотека Львівського національного університету імені Івана Франка, sygn. 604.III, 605.III. 


\section{Edycje źródłowe}

Cantemir D., Vita Constantyni Cantemyri, cognomento senis Moldaviae Principis, w: idem, Opere principelui Demetriu Cantemiru publicate, t. VII, ed. Academia Română, Bucureşti I883.

Dalerac F. P., Les anecdotes de Pologne ou mémoires secrets du règne de Jean Sobieski III du nom, Amsterdam i699, t. 2.

Documente privatore la Istoria Românilor culese de Eudoxiu de Hurmuzaki. Corespondenţa diplomatică şi rapoarte consulare franceze (I603-I824) publicate dupā copile Academiei Române de Nerva Hodoş, t. I6, Bucureşti I9I2.

Dupont P., Pamiętniki historyi życia i czynów Jana III Sobieskiego, tłum. B. Spieralska, wstęp i oprac. D. Milewski, Warszawa 20 II.

Lettere militari con un piano di riforma dell'esercito polacco del Re Giovanni Sobiecki(!) ed altre de'suoi segretari italiani al Gran Duca di Toscana Cosimo ed alla sua segretaria trovate e pubblicate da Sebastiano Ciampi, presso Borgii e Compagni, Firenze I830.

Neculce I., Letopiseţul Tării Moldovei de la Dabija-Vodă până la a doua domnie a lui Constantin Mavrocordat, ed. A. şi Dan Vidraşcu, Chişinău $200 \mathrm{.}$.

Pasek J. Ch., Pamiętniki, t. 2, wyd. S. Sierpowski, Wrocław 2006.

Relacje nuncjuszów apostolskich i innych osób o Polsce od roku I548 do I69o, wyd. E. Rykaczewski, t. 2, Berlin-Poznań I864.

Sarnecki K., Pamiętniki z czasów Jana Sobieskiego, t. I, Diariusz I69o-I695, wyd. J. Woliński, Wrocław 2010.

\section{Literatura przedmiotu}

Andrusiak M., Józef Szumlański: pierwszy biskup unicki lwowski (I667-I708): zarys biograficzny, Lwów 1934 .

Bagińska E., Fond Radziwiłłów w Państwowym Archiwum Historycznym Białorusi w Mińsku, „Białostocczyzna”, R. 49, I998, z. I, s. 58-63.

Barącz S., Pamiatki miasta Żółkwi, Lwów I852.

Barwiński E., Archiwum ks. Radziwiłłów w Nieświeżu. Rys jego historii i sprawozdanie z poszukiwań, „Archiwum Komisji Historycznej PAU”, t. II, Kraków I909.

Bondyra W., Greckokatolickie fundacje szlacheckie na Rusi Czerwonej w czasach saskich, „Res Historica” 2004, z. I7, s. 63-75.

Constantinov W., Primul document original descoperit din arhiva mitropoliei Moldovei înstrăinată la I686, „Arhiva Moldaviae”, t. 2, 20I0, s. I89-I92.

Constantinov W., Noi documente originale din arhiva mitropoliei Moldovei înstrăinată la I686 şi o istorie a mănăstirii Putna într-un pergament din secolul al XVIII-lea, w: Retrospecții medievale. In honorem Professoris emeriti Ioan Caproșu, ed. Victor Spinei, Laurențiu Rădvan, Arcadie M. Bodale, Iași, Editura U medievale. In honorem Professoris emeriti Ioan Caproșu, ed. V. Spinei, L. Rădvan, A. M. Bodale, Iași 20I4, S. I4I-I55.

Chowaniec Cz., Wyprawa Sobieskiego do Mołdawii w I686 r., wyd. 2, Oświęcim 2015.

Chowaniec Cz., Z dziejów polityki Jana III Sobieskiego na Bliskim Wschodzie I683-I686, „Kwartalnik Historyczny”, I926, t. 40, s. I5I-I60.

Chowaniec Cz., Z dziejów powiedeńskiej polityki Jana III. Do genezy sprawy wschodniej, „Przegląd Współczesny”, I929, t. 30, s. 322-34I.

Chowaniec Cz., Miron Costin en Pologne, contributions à l'année I684-I685, Cluj I93I. 
Ciobanu Ş., Contribuţiuni privitoare la originea şi moartea mitropolitului Moldovei Dosofteiu, Bucureşti 1920.

Ciobanu V., Jan III Sobieski w historiografii rumuńskiej, „Śląski Kwartalnik Historyczny. Sobótka", 1980, t. 35, z. 2, s. 223-227.

Czamańska I., Oswobodziciel czy najeźdźca? Polityka Jana III Sobieskiego wobec hospodarstw Mołdawii i Wołoszczyzny, „Roczniki Historyczne”, R. 55-56, I989/1990, s. I5I-I77.

Czamańska I., Rumuńska imigracja polityczna w Polsce XVII wieku, „Balcanica Posnaniensia", I993, t. 6, s. 5-2I.

Czamańska I., Miron Costin. Życie i twórczość, w: Latopis ziemi mołdawskiej i inne utwory historyczne, wyd. I. Czamańska, Poznań I998, s. 47-60.

Czamańska I., From the Moghilas to Dosoftei. The Polish-Romanian Relations in the I7th Century, w: Romanian and Polish Peoples in East-Central Europe $\left(I 7^{\text {th }}-2 O^{\text {th }}\right)$, red. V. Ciobanu, Iaşi 2003, s. I3-26.

Czarniecka A., Nikt nie stucha mnie za życia... Jan III Sobieski w walce z opozycyjna propaganda (I684-I696), Warszawa 2009.

Czarniecka A., Przenikanie się sfery publicznej i prywatnej w życiu Jana III Sobieskiego i Marii Kazimiery, „Barok. Historia - Literatura - Sztuka”, R. I8, 20II, nr 2, s. I3-28.

Чухлиб Т., Львивский єпископ Йосиф Шумлянський - війсковий діяч та дипломат корони польской (6о-ті роки XVII - початок XVIII cm.), „Україна: культурна спадщина, національна свідомість, державність”, 20I2, t. 23, s. 530-589.

Dan D., Dosoftei, mitropolitul Moldovii I624-I693, Cernăuţi 1927.

De Caprio F., Il tramonto di un regno. Il declino di Jan Sobieski dopo il trionfo di Vienna, Viterbo 20I4.

Deruga A., Biskup Józef Szumlański (I667-I708), Lwów 1935.

Dinulescu Ş., Viaţa şi scrierile lui Dositeiu mitropolitul Moldovei, „Candela”, I885, t. 4, s. $69-423$.

Gębarowicz M., Szkice z historii sztuki XVII w., Toruń I96o.

Gołubowicz A. K., Dokumenty i materiały rodu Radziwiłłów w Narodowym Archiwum Historycznym Białorusi w Mińsku, „Miscellanea Historico-Archivistica”, I997, t. 8, s. 93-97.

Hopp L., Ruch niepodległościowy szlachty węierskiej przeciwko Habsburgom a Sobieski, „Śląski Kwartalnik Historyczny. Sobótka”, I980, t. 35, z. 2, s. 229-235.

Iorga S., Sobieski et les Roumains I683-I696, Paris I933.

Jankowski R., Archiwiści i instrukcje archiwalne napisane dla nich w Archiwum Głównym Radziwiłłów w Nieświeżu, ,Archiwista Polski”, R. 5, 2000, nr 2 (I8), s. 309-340.

Jankowski R., Burzliwe losy Archiwum Radziwitłów z Nieświeża od XV w. do I838 r., „Miscellanea Historico-Archivistica", 2000, t. II, s. 35-68.

Jankowski R., Prace inwentaryzacyjne w Archiwum Głównym Radziwiłłów w Nieświeżu do I945 r., „Archiwista Polski”, R. 5, 2000, nr 3(I9), s. 4-55.

Jankowski R., Archiwum Radziwitłów z Nieświeża od I838 r. do XX w. „Miscellanea Historico-Archivistica", 200I, t. I3, S. I3I-I68.

Kasterska Sergescu M., L'expédition de Sobieski en Moldavie en I686, „Revue Historique du Sud-Est Européen", I933, vol. I0, fasc. I, s. I7-30.

Kocój E., Przepis na patrona. O kulcie Jana Nowego Suczawskiego na ziemiach rumuńskich, w: Sprawozdania z posiedzeń Komisji PAN, t. 43/I, I999, s. I8-2I.

Kocój E., Światynie - postacie - ikony. Malowane cerkwie i monastyry Bukowiny Poludniowej w wyobrażeniach rumuńskich, Kraków 2006. 
Кубай М., Дати і подї в історії изеркви Різдва Христового і монастиря отців Василіан у Жовкві, w: Жовква крізь століття, Видавничо-виробниче підприємство «Місіонер», t. I, 20Iо, s. 88-94.

Лазорак Б., Духовна феміда і иеековне братство Різдва Христового в Жовкві (друга половина XVII - XVIII cm.), „Історія релігій в Україні”, 20Iо, t. I, s. 98-Іо6.

Лазорак Б., Інституичійне оформлення ичерковного братства Різдва Христового в Жовкві (XVII-XVIII cm.) w: Жовква крізь століття Видавничо-виробниче підприємство «Місіонер», t. I, 20Iо, s. Iо6-I32.

Лазорак Б., Внутрішнє середовище цеерковного братство Різдва Христового в Жовкві та його правові взаемини з васнліанами в другої половини XVII-XVIII cm., w: Жовква крізь століття Видавничо-виробниче підприємство «Місіонер», t. 2, 20I2, s. I09-I34.

Lorens B., Uniccy biskupi przemyscy a meskie klasztory bazyliańskie w latach I69I-I793, w: Klasztor w Kościele średniowiecznym i nowożytnym, red. M. Derwich, A. Pobóg-Lenartowicz, Warszawa 20I0, s. 203-2I7.

Lorens B., Sytuacja gospodarcza monasterów bazyliańskich w Galicji u progu kasat józefińskich oraz losy ich majątku po kasacie. Zarys problemu, w: Klasztor $w$ gospodarce średniowiecznej i nowożytnej, red. M. Derwich, Wrocław 2013, s. 623-643.

Lorens B., Bazylianie prowincji koronnej w latach I743-I780, Rzeszów 2014.

Lorens B., Bazylianie w Galicji wobec działań kasacyjnych w latach I772-I792, w: Kasaty klasztorów na obszarze dawnej Rzeczypospolitej Obojga Narodów i na Ślasku na tle procesów sekularyzacyjnych w Europie, t. I, Geneza kasaty na ziemiach zaborów austriackiego i rosyjskiego, red. M. Derwich, Wrocław 20I5, s. 215-232.

Macyszyn J., Żółkiewska kolegiata - pomnik chwały żotnierskiej, w: Biblioteka epoki nowożytnej, t. 2, Sobieski wokót spisków i konfederacji, red. M. Nagielski, Warszawa 20I5, s. $187-203$.

Manyś B., Tajemnica relikwii św. Lucyda, czyli o obchodach okolicznościowych świą sakralnych w Wilnie w czasach Augusta III. Przyczynek do badań, „Czas Przeszły”, 20I6, t. 3, nr I-2, s. 3I-47.

Mańkowski T., Mecenat Jana III w Żółkwi, „Prace Komisji Historii Sztuki”, I948, t. 9, s. I-26. Marian S. Fl., Sântul Ioan cel Nou de la Suceava. Schiţa istorică, Bucureşti I895.

Mączyński R., Nowożytne konfesje polskie. Artystyczne formy gloryfikacji grobów świętych i błogosławionych $w$ dawnej Rzeczypospolitej, Torun 2003.

Mączyński R., Włoscy męczennicy pod niebem Pólnocy: rozważania nad problematyka importu i kultu relikwii świętych, w: Artyści włoscy w Polsce XV-XVIII wiek, red. J.A. Chrościcki, Warszawa 2004, s. 87-I42.

Milewski D., Wojenne interludium. Stosunki polsko-mołdawskie w latach I676-I683, w: Król Jan III Sobieski i Rzeczpospolita w latach I674-I683, red. D. Milewski, Warszawa 20I6, S. 227-257.

Petrus J. T., Kościoły i klasztory Żółkwi. Materiały do dziejów sztuki sakralnej na ziemiach wschodnich dawnej Rzeczypospolitej, cz. I, Kościoły i klasztory rzymskokatolickie dawnego województwa ruskiego, Kraków I994.

Pietrzak J., Kult loretański w kręgu rodziny Sobieskich, „Studia Wilanowskie”, 20I4, t. XXXI, S. I03-II4.

Pietrzak J., Erinnerungen an die „Victoria“ Die Jahrestage des Entsatzes von Wien I683 als Propagandainstrument der Regierenden, „Historie. Jahrbuch des Zentrums für 
Historische Forschung Berlin der Polnischen Akademie der Wissenschaften", 20I6, Folge I0, s. 44-63.

Popovici Gh., Index Zolkiewiensis, „Candela”, t. 3 (I884), s. 54I-757.

Scărlătescu D., Cărtuari Români în Galiţia. Pe urmele tezaurului mitropolitan al Moldovei, w: Românii din afara graniţlor ţării. Iaşi-Cernăuţi: legături istorice, red. I. Pruteanu-Isăcescu, A. Zub, Iaşi-Cernăuţi-Herţa-Edineţ 20I2, s. 3-36.

Sileoni M. L., La difficile campagna militare anti-turca in Moldavia di Jan III Sobieski (I686) nella carte vaticane, w: L'Europa centro-orientale e pericolo turco tra Sie- e Settecento. Atti del Convegno Internazionale (Viterbo, 23-25 Novembre 1998), red. G. Platania, Viterbo I998, s. I73-I9I.

Skrzypietz A., Królewscy synowie - Jakub, Aleksander i Konstanty Sobiescy, Katowice $201 \mathrm{I}$.

Слободня В., Українські ичеркви Жовкви від найдавніших часів до середини ХХ ст., w: Жовква крізь століття, Видавничо-виробниче підприємство «Місіонер», t. I, 20IO, s. 22I-234.

Smolarek P., Kampania mołdawska Jana III roku I69I, Oświęcim 2015.

Sokołowski M., Spadek po metropolicie Doziteuszu i jego losy, „Sprawozdania Komisyi do badań historii sztuki PAU", I889, t. 4, z. 2, s. 3-85.

Sommer-Mathias A., Trzysta lat króla Jana III Sobieskiego na wiedeńskich scenach. Pamięć o „Turkach”, medialna inscenizacja i propaganda polityczna [Muzeum Pałac Jana III w Wilanowie, http://www.wilanowpalac.art.pl/trzysta_lat_krola_jana_iii_sobieskiego_na_wiedenskich_scenach_pamiec_o_turkach_medialna_inscenizacja_i_propaganda_polityczna.html].

Spieralski Z., Awantury mołdawskie, Warszawa 1967.

Staszewski J., Królewicz Aleksander Sobieski kandydatem do korony węgierskiej, „Śląski Kwartalnik Historyczny. Sobótka", I980, t. 35, z. 2, s. 39I-398.

Szymczuk E., Kwerenda archiwaliów w Mińsku, „Archeion”, I997, t. 97, s. 408-4I2.

Śliziński J., Jan III Sobieski w literaturze narodów Europy, Warszawa 1979.

Tollet D., La reconquête catholique en Moldavie sous le règne de Jean III Sobieski, w: L'Europa centro-orientale e pericolo turco tra Sie- e Settecento. Atti del Convegno Internazionale (Viterbo, 23-25 Novembre 1998), red. G. Platania, Viterbo I998, s. 193-215.

Wagner M., W cieniu szukamy jasności chwały. Studia z dziejów panowania Jana III Sobieskiego (I684-I696), Siedlce 2002.

Wędkiewicz S., Z tradycji rumuńskich o Janie III Sobieskim, w: Studia staropolskie. Księga pamiatkowa ku czci Aleksandra Brücknera, Kraków 1928.

Woliński J., Po Chocimie I673-I674, „Przegląd Historyczny”, I948, t. 37, s. 288-305.

Woliński J., Ze spraw polsko-mołdawskich I672-I673, w: Z dziejów wojen polsko-tureckich, red. J. Woliński, Kraków I983, s. 5I-59.

Woliński J., Z dziejów wojen polsko-tureckich, Warszawa I983.

Wójcik Z., Jan Sobieski I629-I696, Warszawa I983.

Zielińska T., Archiwa Radziwiłłów i ich twórcy, „Archeion”, I978, t. 66, s. I05-I29.

Zielińska T. Archiwalia różnych linii rodu Radziwiłtów w polskich zbiorach publicznych, „Miscellanea Historico-Archivistica”, I997, t. 8, s. I07-II3.

Zielińska T., Archiwa wielkich rodów Rzeczypospolitej dziedzictwem narodów Europy Środkowej i Wschodniej, „Archiwista Polski”, I999, nr 2 (I4), s. 33-40. 